Jurnal Pengurusan 61(2021) $95-108$

https://doi.org/10.17576/pengurusan-2021-61-08

\title{
Penggunaan Media Sosial di Tempat Kerja dan Tingkah Laku Inovatif Pekerja dalam Kalangan Milenial
}

\author{
(Social Media Usage in Workplace and Employee Innovative Behaviour among Millennials) \\ Roshayati Abdul Hamid \\ (Fakulti Ekonomi dan Pengurusan, Universiti Kebangsaan Malaysia) \\ Ida Rosnita binti Ismail \\ (UKM-Graduate School of Business, Universiti Kebangsaan Malaysia)
}

ABSTRAK

Penyumbang utama kepada inovasi organisasi adalah pekerja yang mempunyai tingkah laku inovatif. Kajian ini menekankan kepentingan penggunaan media sosial di tempat kerja dalam mendorong tingkah laku inovatif pekerja. Konteks kajian adalah generasi Milenial kerana mereka sedang mendominasi alam pekerjaan dan menerajui inovasi organisasi. Oleh itu, objektif kajian ini adalah untuk menguji penggunaan media sosial yang mampu memupuk tingkah laku inovatif dalam kalangan Milenial di tempat kerja dan karakteristik kerja Milenial sebagai pengantara hubungan tersebut. Borang soal selidik diagihkan secara atas talian kepada pekerja Milenial di beberapa buah organisasi di Malaysia. Data yang diperolehi telah diuji menggunakan kaedah PLS-SEM dan hasil kajian menunjukkan terdapat hubungan yang signifikan antara penggunaan media sosial dengan tingkah laku inovatif pekerja Milenial dan karakteristik kerja Milenial adalah pengantara separa hubungan tersebut. Kajian ini dapat menambahkan bukti empirikal kepada badan pengetahuan dan secara praktikalnya organisasi perlu peka dengan corak pengurusan kerja Milenial yang seiring dengan perkembangan teknologi.

Kata Kunci: Penggunaan media sosial; karakteristik kerja milenial; tingkah laku inovatif pekerja; inovasi organisasi; milenial; PLS-SEM.

\section{ABSTRACT}

A major driver to the organizational innovation is an employee who has innovative behavior. This study emphasizes the importance of the social media usage in workplace in encouraging employee innovative behavior. Context of this study is Millennial because are dominating the world of work and lead organizational innovation. Therefore, the objective of this study is to test the social media usage in fostering innovative behavior among Millennials in the workplace and Millennial's job characteristics as a mediator of the relationship. The questionnaires were distributed to Millennial in several organizations in Malaysia. Data obtained were tested using the PLS-SEM method and the results showed that there is a significant relationship between the social media usage in the workplace with the innovative behavior and Millennial job characteristics mediates the relationship. This study will add empirical evidence to the body of knowledge and practically the organization needs to be sensitive to the Millennial working style in line with technology development.

Keywords: Social media usage; millennial job characteristic; employee innovative behaviour; organizational innovation; millennial; PLS-SEM

\section{PENGENALAN}

Perubahan persekitaran yang dinamik dan kerancakan penggunaan teknologi dalam dunia perniagaan telah memberi cabaran baru kepada organisasi. Organisasi perlu berinovasi untuk meneruskan kelangsungan, mengekalkan kelebihan daya saing dan meningkatkan prestasi perniagaan mereka (Korzilius et al. 2017). Inovasi merupakan salah satu keperluan kerana dengan inovasi organisasi mampu menterjemahkan idea baru menjadi produk baru, perkhidmatan baru dan membuat penambahbaikan terhadap proses kerja supaya dapat memberikan kelebihan dan meningkatkan daya saing (Cekmecclioglu \& Ozbag 2016). Keberhasilan inovasi bermula dari penjanaan idea yang kreatif, baru dan berguna dari pekerja (Agarwal 2014; De Spiegelaere et al. 2016). Oleh itu, organisasi sangat memerlukan pekerja yang mempunyai pemikiran kreatif dan tingkah laku inovatif untuk merealisasikan strategi inovasi mereka.

ekerja yang berinovatif adalah penting kepada organisasi dalam mendepani cabaran persekitaran dinamik. Justeru, usaha penyelidik dalam meneroka faktor yang mendorong tingkah laku inovatif pekerja di organisasi telah mendapat perhatian. Kajian terdahulu telah membuktikan secara empirikal bahawa faktor kontekstual seperti gaya kepemimpinan (Wang \& Zhu 2018) dan faktor individual seperti personaliti (Birdi et al. 2014; Chen et al. 2013; Thurlings et al. 2014) merupakan 
antara pendorong tingkah laku inovatif pekerja. Namun, masih banyak lagi ruang untuk memperluaskan pemahaman tingkah laku inovatif pekerja (Hou et al. 2018) terutamanya dalam kalangan generasi $Y$ atau generasi Milenial yang disebut Milenial (dalam kajian ini) yang mula mendominasi dunia pekerjaan menjelang 2020 (Gulyani \& Batnagar 2017). Oleh itu, organisasi perlu mengorak langkah dalam mengatur strategi yang bersesuaian dengan karakteristik Milenial untuk memastikan mereka cenderung ke arah tingkah laku yang berinovatif.

Tenaga kerja sedang mengalami perubahan dramatik dengan kehadiran Milenial iaitu mereka yang dilahirkan antara tahun 1980 - 1999 (Twenge \& Campbell 2008) yang digambarkan sebagai generasi terbesar dalam tren pertumbuhan penduduk dunia (Savaneviciene et al. 2019). Organisasi amat bergantung kepada generasi ini yang bakal menjadi tulang belakang dan nadi organisasi untuk mendepani cabaran persekitaran perniagaan yang dinamik (Trapero et al. 2017). Milenial memiliki karakteristik yang berbeza dari generasi sebelumnya (Twenge 2010). Generasi ini mempunyai jangkaan yang berbeza dalam kehidupan dan pekerjaan yang membawa kepada perbezaan dari sudut persepsi nilai, keperibadian serta sikap di tempat kerja (Lyons \& Kuron 2014). Berkeupayaan untuk melakukan pelbagai tugasan, berorientasikan kerja berpasukan, cenderung untuk melakukan tugasan yang kompleks dan mencabar serta mengharapkan maklum balas dari pengurusan untuk pembangunan diri dan kerjaya adalah antara karakteristik Milenial (Bannon et al. 2011; Zelga 2018). Karakteristik tersebut mampu meningkatkan inspirasi dan motivasi mereka untuk memberikan hasil kerja yang positif (Kim et al. 2009; Wrzesniewski \& Dutton 2001). Tambahan pula, kelebihan Milenial yang dibesarkan seiring dengan perkembangan teknologi (Zelga 2018) memudahkan mereka untuk melangkah ke alam pekerjaan berbekalkan pengetahuan teknologi yang ada.

Pendedahan awal terhadap teknologi juga telah menjadikan Milenial bergantung hampir sepenuhnya kepada Internet terutama media sosial (Bolton et al. 2013) dalam pelbagai aspek kehidupan mereka (Badri et 1. 2020). Justeru, keberadaan Milenial dalam dunia pekerjaan telah merancakkan penggunaan media sosial di tempat kerja. Penggunaan media sosial dapat memudahkan urusan organisasi seperti melancarkan aktiviti pemasaran (Crammond et al. 2018; $\mathrm{Hu}$ et al. 2017), memudahkan perkongsian maklumat antara majikan dan pekerja (Taylor et al. 2015) dan membolehkan komunikasi dua hala dalam memperolehi maklum balas dari pengguna (Crammond et al. 2018). Malah, penggunaan media sosial juga dapat memupuk sikap dan tingkah laku positif dalam kalangan Milenial dan seterusnya memberi hasil kerja yang signifikan (Chu 2020; Men et al. 2020).

Berdasarkan fenomena semasa dunia perniagaan dan cabaran yang mesti dihadapi oleh organisasi untuk kekal berdaya saing dalam persekitaran yang dinamik, organisasi perlu mempelbagaikan usaha untuk memupuk tingkah laku inovatif pekerja dalam kalangan Milenial. Walaupun pelbagai kajian telah dijalankan oleh penyelidik terdahulu, namun penyelidikan yang berkaitan dengan penggunaan media sosial sebagai pendorong kepada tingkah laku inovatif dalam kalangan Milenial masih kurang dikaji. Ianya bertepatan dengan karakteristik Milenial yang celik teknologi serta mula mendominasi dunia pekerjaan dan bakal menerajui kecemerlangan organisasi. Oleh itu, kajian ini adalah bertujuan untuk menguji sama ada penggunaan media sosial dalam kalangan Milenial mampu mendorong meningkatkan tingkah laku inovatif dan turut menguji sama ada karateristik kerja generasi ini bertindak sebagai pengantara yang memberi kelebihan kepada peningkatan tingkah laku inovatif tersebut.

\section{KAJIAN LITERATUR DAN PEMBANGUNAN HIPOTESIS}

\section{TINGKAH LAKU INOVATIF PEKERJA}

Inovasi merupakan pemacu utama pertumbuhan organisasi dan kelebihan daya saing (Amabile 1988; Korzilius et al. 2017). Pekerja merupakan sumber penting kepada inovasi kerana tingkah laku inovatif pekerja adalah pendorong kepada inovasi organisasi (Agarwal 2014; De Spiegelaere et al. 2016). Tingkah laku inovatif pekerja dapat didefinisikan sebagai kemampuan mereka untuk menghasilkan idea baru dan melaksanakan idea tersebut dalam tugasan yang berkaitan dengan pekerjaan yang dapat memberi manfaat kepada kecemerlangan organisasi (Akram et al. 2018; Scott \& Bruce 1994). Tingkah laku inovatif merangkumi tiga aktiviti tingkah laku yang berbeza iaitu penjanaan, mempromosikan dan merealisasikan idea baru atau penambahbaikan idea sedia ada (Scott \& Bruce 1994; Janssen 2000). Dalam erti kata lain, konsep tingkah laku inovatif pekerja adalah merujuk kepada proses untuk menghasilkan inovasi yang dicetuskan dari idea yang kreatif. Jika pekerja mampu untuk menyumbang secara signifikan dalam membangunkan idea baru berkaitan produk, perkhidmatan dan proses kerja, maka pekerja memiliki tingkah laku yang inovatif (Hamid et al. 2020).

Kajian mengenai faktor pendorong kepada tingkah laku inovatif pekerja terus meningkat dan masih mendapat perhatian penyelidik (Wang et al. 2021). Secara spesifiknya, faktor-faktor yang dikaji dapat diklasifikasikan kepada faktor individu dan faktor kontekstual (Wang \& Zhu 2018). Antara faktor individu yang menjadi pendorong kepada tingkah laku inovatif pekerja adalah motivasi dan keberkesanan diri (Thurlings et al. 2014) serta keupayaan kognitif dan personaliti (Wang \& Zhu 2018). Pekerja yang mempunyai tahap pengetahuan, kebolehan dan pengalaman yang tinggi juga dapat menyumbangkan idea baru kepada organisasi (Birdi et al. 2014). Faktor psikologi juga sering dikaitkan sebagai penyederhana dan pengantara kepada tingkah 
laku inovatif pekerja seperti modal psikologi (Fang et al. 2019) dan pemerkasaan psikologi (Groselj et al. 2020). Manakala faktor kontekstual yang kerap diuji ialah faktor gaya kepimpinan seperti kepimpinan transformasi (Groselj et al. 2020) dan kepimpinan hamba (Iqbal et al. 2020). Gaya kepimpinan dapat menentukan sejauh mana pemerkasaan dan autonomi diberikan kepada pekerja supaya mereka dapat membina kreativiti yang kemudiannya membawa kepada tingkah laku inovatif pekerja (Slatten \& Mehmetoglu 2015). Selain gaya kepimpinan, budaya dan iklim organisasi (Scott \& Bruce 1994) serta karakteristik kerja juga didapati menyokong kreativiti dan inovatif pekerja (Wang \& Zhu 2018; West \& Sacramento 2012).

Berdasarkan beberapa ulasan kajian lepas mengenai pendorong kepada tingkah laku inovatif pekerja, kebanyakan kajian memfokuskan kepada perspektif kontekstual dan individual (Marin-Garcia et al. 2011). Hasil dapatan kajian lepas membuktikan pekerja yang mempunyai bakat tersendiri mampu berfikir di luar kotak, mempunyai sifat keterbukaan, mempunyai pemikiran kritikal dan kreatif dan bersikap positif dan mampu mendepani cabaran (Parzefall et al. 2008) di samping mendapat sokongan dari pihak pengurusan serta persekitaran organisasi yang kondusif (Wang et al. 2021). Selain dari memfokuskan kepada pekerja dari semua generasi secara umum, kajian secara spesifik kepada generasi Milenial adalah wajar dijalankan memandangkan jumlah mereka yang semakin meningkat di tempat kerja serta memiliki karakteristik yang unik (Zelga 2018).

\section{PENGGUNAAN MEDIA SOSIAL DI TEMPAT KERJA DAN} TINGKAH LAKU INOVATIF PEKERJA MILENIAL

Perkembangan teknologi Internet telah menjadikan media sosial sebagai saluran komunikasi yang paling utama di Malaysia. Menurut statistik yang dikeluarkan oleh Suruhanjaya Komunikasi dan Multimedia Malaysia, 93.3\% pengguna Internet telah menggunakan media sosial untuk pelbagai tujuan dalam kehidupan dan pekerjaan (MCMC 2020). Media sosial telah menjadi saluran komunikasi yang bukan sahaja dapat menghubungkan individu dalam dan luar organisasi, malah merupakan platform perniagaan yang efisien (Men et al. 2020). Media sosial telah membawa suatu pembaharuan dalam pengurusan organisasi, iaitu bermula daripada penciptaan model perniagaan yang inovatif sehingga mengubah cara komunikasi, kerjasama, pencarian dan perkongsian maklumat (Ali-Hassan et al. 2015). Media sosial juga dapat mendorong pembelajaran organisasi dan inovasi (Leonardi et al. 2013) untuk meningkatkan produktiviti dan prestasi organisasi serta menguruskan cabaran ketika menghadapi perubahan persekitaran yang dinamik (Cao \& Ali 2008; Cetinkaya \& Rasyid 2018).

Penggunaan media sosial bukan sahaja dapat memberi kesan yang positif kepada organisasi tetapi juga kepada pekerjanya (Chu 2020). Kajian telah membuktikan secara empirikal bahawa penggunaan media sosial berorientasikan kerja telah menghasilkan tingkah laku yang positif seperti meningkatkan prestasi kerja, kepuasan kerja, komitmen terhadap organisasi serta mampu menjana perkembangan minda dan diri (Cao \& Ali 2018; Chu 2020; Donelan 2016; Men et al. 2020). Perkaitan positif tersebut tercetus apabila pekerja berkongsi pengetahuan dan maklumat tentang produk atau perkhidmatan perniagaan dalam media sosial supaya pengguna boleh mengakses dengan cepat (Ewing et al. 2019; Ferreira 2019) dan memberi maklum balas. Ia membuka ruang kepada pekerja untuk melakukan penambahbaikan terhadap produk atau perkhidmatan tersebut (Istanbulluoglu 2017) dan mendalami jangkaan pengguna dengan memberikan penyelesaian yang terbaik (Meik et al. 2014). Pekerja juga boleh mengakses maklumat mengenai produk atau perkhidmatan organisasi lain melalui media sosial. Maklumat tersebut dapat mendorong pekerja untuk menghasilkan idea yang lebih kreatif dalam perancangan semula proses perniagaan (business process reengineering) dan menghasilkan sesuatu yang lebih berinovasi (Pudliner et al. 2015) kepada organisasi. Media sosial juga berperanan untuk menghubungkan antara pembekal-pengusaha-pelanggan (Markova \& Petkovska-Mircevska 2013) di mana segala cadangan atau komen pelanggan dapat disalurkan secara telus kepada pembekal supaya sama-sama dapat memikirkan cara penyelesaian yang terbaik. Oleh itu, dapat disimpulkan bahawa interaksi diantara pekerjapengguna, maklumat pesaing dan kerjasama antara pembekal-pengusaha-pelanggan mampu mendorong pekerja untuk berfikir secara kreatif bagi menghasilkan idea yang lebih bernas (Crammond et al. 2018) lalu meningkatkan tingkah laku pekerja yang berinovatif.

Berdasarkan ulasan di atas, ternyata penggunaan media sosial berorientasikan kerja dapat mempengaruhi sikap dan tingkah laku pekerja (Men et al. 2020) ke arah yang lebih positif (Alalwan et al. 2017; Cao \& Ali 2018). Penggunaan media sosial di tempat kerja dapat dirancakkan lagi dengan kehadiran generasi Milenial (Sigala et al. 2012) yang mula mendominasi dunia pekerjaan sekarang ini (Gulyani \& Batnagar 2017). Ianya bertepatan dengan kehebatan generasi ini dalam mengendalikan dan menggunakan teknologi terkini kerana karakteristik mereka yang celik teknologi (Zelga 2018). Milenial mampu menggunakan media sosial untuk pelbagai tujuan yang memberi manfaat kepada organisasi (Tsimonis \& Dimitriadis 2014) dalam mendepani dunia teknologi moden (Sony \& Naik 2019). Di samping itu, penggunaan media sosial juga dapat meningkatkan prestasi pekerja (Landers \& Schmidt 2016) dan mencetuskan pemikiran kreatif (Crammond et al. 2018). Oleh itu, kajian ini menjangkakan pemikiran kreatif yang terhasil dari penggunaan media sosial dalam kalangan Milenial berupaya menghasilkan sesuatu yang berinovasi melalui tingkah laku inovatif mereka (Scott \& Bruce 1994; Janssen 2000). 
Kajian ini didasari oleh Model Penerimaan Teknologi (Technology Acceptance Model/TAM) dan memfokuskan kepada persepsi kebergunaan dan persepsi mudah guna media sosial di tempat kerja. TAM telah dibangunkan oleh Davis (1989). Model ini mencerminkan motivasi pengguna untuk menerima dan menggunakan teknologi baru (Wu 2009). Ia merangkumi beberapa pemboleh ubah motivasi seperti kebergunaan, mudah guna dan tingkah laku terhadap penggunaan teknologi. Motivasi tersebut sering dikaitkan dengan niat dan penggunaan teknologi (Scherer et al. 2019). Namun, pemboleh ubah yang kerap digunakan dalam kajian adalah kebergunaan dan mudah guna teknologi yang digandingkan dengan beberapa pemboleh ubah lain (Marangunic \& Granic 2015). Di samping itu, beberapa penyelidik (contoh: Lin et al. 2011; Taherdoost 2017) turut mencadangkan beberapa pemboleh ubah luaran perlu ditambah ke dalam model TAM untuk memberi ramalan yang lebih konsisten mengenai penggunaan sesuatu sistem. Menurut TAM, pekerja lebih kerap menggunakan media sosial dalam urusan pekerjaan apabila mereka percaya bahawa ianya sangat berguna (usefulness) sebagai saluran komunikasi dan mudah untuk digunakan (ease of use) ke arah tingkah laku yang positif untuk meningkatkan pencapaian dalam pekerjaan (Matikiti et al. 2018).

Oleh itu, objektif pertama kajian ini adalah untuk menguji sejauh mana penggunaan media sosial di tempat kerja dalam kalangan Milenial dapat mendorong tingkah laku inovatif pekerja dengan hipotesis berikut:

$\mathrm{H}_{1} \quad$ Terdapat hubungan yang positif antara penggunaan media sosial di tempat kerja dan tingkah laku inovatif pekerja.

PEMBOLEH UBAH PENGANTARA KARAKTERISTIK KERJA GENERASI MILENIAL DAN TINGKAH LAKU INOVATIF PEKERJA MILENIAL

Model karakteristik kerja telah menyediakan kerangka untuk memahami sejauh mana pekerja merasakan pekerjaan mereka dapat memberi inspirasi dan motivasi (Hackman \& Oldham 1976; Piccolo \& Colquitt 2006) yang mencetuskan hasil kerja yang positif. Pada dasarnya, model ini mencadangkan lima dimensi karakterisk kerja iaitu kepelbagaian tugas, kepentingan tugas, identiti tugas, autonomi dan maklum balas. Namun, terdapat juga kajian yang memfokuskan hanya kepada karakteristik tertentu sahaja seperti karateristik tugasan dan pengetahuan (Vui-Yee \& Paggy 2018), autoriti untuk membuat keputusan, autonomi dan penggunaan kemahiran (Humphrey et al. 2007) serta kompleksiti kerja, tekanan kerja dan autonomi (Wang \& Zhu 2018).

Kajian terdahulu membuktikan bahawa karakteristik kerja dapat membuahkan hasil kerja yang positif seperti kepuasan kerja, pembangunan diri, kesetiaan kepada organisasi dan keberkesanan kerja (De Varo \& Brookshire, 2007; Vui-Yee \& Paggy 2018). Malah di dalam kajian yang berkaitan dengan inovasi, karakteristik kerja menunjukkan hubungan yang signifikan dengan tingkah laku inovatif dan kreativiti pekerja (Hammond et al. 2011; Wang \& Zhu 2018). Antara karakteristik kerja yang dapat meningkatkan motivasi pekerja ke arah memupuk kreativiti adalah kerja yang kompleks dan memerlukan kepelbagaian kemahiran (Wang \& Zhu 2018) serta kerja yang mencabar dan diberi autonomi (Kurz et al. 2018). Karakteristik kerja tersebut telah membuatkan pekerja berasa kompeten dan dapat meningkatkan minat terhadap kerja (Axtell et al. 2000). Menurut Amabile et al. (1996), pekerja yang mempunyai minat dan merasa gembira dengan kerja mereka akan menjadi lebih kreatif.

Pekerja Milenial juga memiliki karakteristik kerja yang berpotensi untuk memberi motivasi ke arah tingkah laku yang positif di tempat kerja. Kebolehan Milenial dalam penggunaan teknologi telah meningkatkan kecenderungan untuk menggunakan media sosial dalam urusan pekerjaan (Badri et al. 2020). Kebolehan mereka telah memberi nilai-tambah kepada organisasi (Twenge et al. 2010) dengan mempermudahkan urusan perniagaan digital (Zelga 2018) di samping mendorong generasi ini untuk melakukan pelbagai tugasan yang kompleks dan mencabar (Wang \& Zhu 2018). Penggunaan media sosial juga telah menggalakkan interaksi melalui komunikasi elektronik dengan lebih cekap dan dapat memberi kebebasan kepada Milenial untuk melaksanakan kerja di mana sahaja (Bogosian \& Rousseau 2017). Persekitaran kerja yang fleksibel ini dapat meningkatkan penghasilan idea yang kreatif (Jena \& Memon 2017).

Selain dari kepintaran teknologi, generasi Milenial telah dibesarkan dalam persekitaran yang mementingkan pelajaran (Bogosian \& Rousseau 2017). Mereka juga dikenali sebagai generasi yang berpendidikan tinggi dan gemar menimba ilmu secara berterusan serta mempunyai personaliti keterbukaan (Cekada 2012). Milenial juga lebih tegas dan lantang untuk menyuarakan pendapat serta cenderung untuk menjalankan tugas yang mereka minat dan bukannya melakukan tugas yang terpaksa mereka lakukan (Deal et al. 2010). Generasi ini berani menyahut cabaran untuk menjalankan projek yang kompleks di mana ia dapat memberi inspirasi kepada mereka untuk mengasah kemahiran berfikir secara kreatif(Zelga 2018). Mereka juga mampu melakukan pelbagai tugasan dalam satu masa dan sukakan sesuatu yang berstruktur (Farrell \& Hurt 2014). Mereka sentiasa mencari peluang untuk meningkatkan pencapaian kerja dan mengharapkan idea serta usaha mereka diberi maklum balas daripada pihak pengurusan (Farrell \& Hurt 2014). Dengan maklum balas tersebut, Milenial boleh berusaha untuk melakukan pembaharuan serta perubahan (Cekada 2012) yang boleh menyumbang kepada keberkesanan organisasi.

Berdasarkan ulasan di atas, terdapat pelbagai karakteristik kerja yang sangat sinonim dengan Milenial di tempat kerja. Secara kolektifnya, Milenial memiliki karakteristik yang mampu mendorong mereka untuk berfikir secara kreatif (Crant 2000; Garlick \& Langley 2007) dan kreativiti ini mampu mendorong kepada tingkah laku inovatif pekerja (Janssen 2000). 
Karakteristik kerja juga sering diuji sebagai pemboleh ubah pengantara. Sebagai contoh, pengantara hubungan di antara penglibatan pekerja dan kesejahteraan pekerja (Holman et al. 2010), di antara personaliti dan kepuasan kerja (Judge et al. 2000), serta pengantara di antara persekitaran kerja dan hasil kerja (Kim et al. 2009). Hasil kajian tersebut telah membuktikan secara empirikal bahawa karakteristik kerja adalah signifikan sebagai pemboleh ubah pengantara. Ia berfungsi sebagai pemboleh ubah penjelasan yang bertujuan untuk mengenal pasti dan menjelaskan bagaimana hubungan antara pemboleh ubah bersandar dan pemboleh ubah tidak bersandar boleh dikukuhkan (Pieters 2017).

Oleh itu, kajian ini ingin menguji hubungan antara penggunaan media sosial, karakteristik kerja Milenial dan tingkah laku inovatif pekerja serta karakteristik kerja sebagai pengantara hubungan antara penggunaan media sosial dan tingkah laku inovatif; hipotesis seperti berikut:

$\mathrm{H}_{2}$ Terdapat hubungan yang positif antara penggunaan media sosial dan karakteristik kerja Milenial.

$\mathrm{H}_{3}$ Terdapat hubungan yang positif antara karakteristik kerja Milenial dan tingkah laku inovatif pekerja.

$\mathrm{H}_{4}$ Karakteristik kerja Milenial sebagai pengantara hubungan antara penggunaan media sosial dan tingkah laku inovatif pekerja.

\section{RANGKA KERJA KAJIAN}

Berdasarkan ulasan kajian lepas, hipotesis kajian telah dibina dan sebuah rangka kerja kajian telah dibangunkan seperti berikut:

RAJAH 1. Rangka kerja kajian

\section{METOD KAJIAN}

\section{SAMPEL DAN PROSEDUR}

Kajian ini menggunakan pendekatan kuantitatif untuk menguji hipotesis yang telah dibina berdasarkan objektif kajian. Sebanyak 250 borang soal-selidik telah diedarkan secara dalam talian menggunakan kaedah pensampelan mudah kepada pekerja di sektor awam dan swasta di Malaysia. Saiz sampel dalam kajian ini melebihi yang dicadangkan oleh Green (1991) atau Green Rule of Thumb yang menyatakan untuk analisis regresi, saiz sampel adalah sama atau melebihi $50+8 \mathrm{~m}$ (di mana $\mathrm{m}$ adalah bilangan pemboleh ubah tidak bersandar). Sektor awam turut dipilih dalam kajian berkaitan inovasi kerana sektor ini telah mula mempergiatkan aktiviti inovasi dalam pengurusan perkhidmatan semenjak corak baru pengurusan sektor awam diperkenalkan (Bysted \& Hansen 2015; Mutonyi et al. 2019). Responden adalah terdiri dari pekerja yang berumur di antara 20 hingga 40 tahun yang mewakili generasi Milenial iaitu mereka yang dilahirkan dari tahun 1980 - 1999 (Twenge \& Campbell 2008). Sejumlah 204 daripada 250 borang soal selidik telah dikembalikan dan digunakan untuk analisis di mana ianya bersamaan dengan $81.6 \%$ kadar maklum balas. Daripada 204 responden yang memberi maklum balas, $58.3 \%$ adalah perempuan dan majoriti berumur dalam lingkungan 20-25 tahun (52\%) manakala selebihnya berumur dalam lingkungan 26 hingga 40 tahun. Majoriti responden kajian ini adalah kakitangan swasta (52.9\%) yang mempunyai pengalaman bekerja antara 1 hingga 5 tahun (57.4\%) serta memiliki Diploma (41.2\%) dan Ijazah (26\%).

\section{PENGUKURAN}

Soal selidik yang berstruktur telah dibentuk untuk ketiga-tiga pemboleh ubah kajian ini, iaitu penggunaan media sosial di tempat kerja, karakteristik kerja Milienal dan tingkah laku inovatif pekerja. Responden menjawab kesemua item soalan dalam soal selidik menggunakan skala 1 (sangat tidak setuju) sehingga skala 5 (sangat setuju). Bagi pemboleh ubah penggunaan media sosial di tempat kerja, soalan diadaptasi daripada kajian Cetinkaya dan Rashid (2018). Responden perlu menjawab dua dimensi item untuk pemboleh ubah ini, iaitu 7 item untuk kebergunaan (usability) media sosial di tempat kerja dan juga 3 item untuk mudah guna (ease of use) media sosial di tempat kerja. Antara contoh item bagi bahagian tersebut adalah "Kebergunaan media sosial di tempat kerja membolehkan saya membuat kerja dengan lebih cepat" dan "Adalah mudah untuk belajar menggunakan media sosial".

Karakteristik kerja Milenial pula diukur dengan menggunakan 6 item yang diadaptasi daripada kajian Farrel dan Hurt (2014). Skala yang sama turut digunakan untuk responden bagi menjawab soalan ini, iaitu skala 1 (sangat tidak setuju) sehingga skala 5 (sangat setuju). Antara contoh soalannya ialah "Saya melihat diri saya sebagai seorang yang suka melakukan pelbagai kerja dalam satu masa" dan "Saya melihat diri saya sebagai seorang yang suka sesuatu kerja yang berstruktur". Tingkah laku inovatif pekerja Milenial pula diukur mengikut 9 item diadaptasi daripada Jannsen (2000). Skala 1 (sangat tidak setuju) sehingga skala 5 (sangat setuju) telah digunakan untuk item ini. Antara contoh item untuk soalan ini adalah "Dalam organisasi, saya mencipta idea baru untuk penyelesaian isu yang sukar" dan "Dalam organisasi, saya mencari kaedah, teknik atau instrumen proses kerja yang baru".

\section{DATA ANALISIS}

Data mentah yang diperolehi melalui soal selidik dianalisis menggunakan teknik partial least squares structural equation modeling (PLS-SEM) dengan perisian SmartPLS 3 (Ringle, Wende \& Becker 
2015). PLS-SEM digunakan di dalam kajian ini bagi membolehkan pengujian terhadap model komponen hierarkikal (hierarchical component model) bagi konstruk penggunaan media sosial. Ia berupaya menerangkan konstruk yang dimodelkan secara abstrak berdasarkan kepada dimensi yang lebih konkrit (Sarstedt et al. 2019). PLS-SEM memerlukan analisis data dilakukan pada dua peringkat iaitu (1) menguji model pengukuran untuk melihat hubungan antara item pengukuran dengan pemboleh ubah tidak bersandar dan pemboleh ubah bersandar; dan (2) menguji model struktur untuk melihat hubungan antara pemboleh ubah tidak bersandar dan pemboleh ubah bersandar (Tenenhaus et al. 2005). Pengujian hipotesis untuk hubungan lansung dan hubungan tidak langsung adalah berdasarkan kepada dapatan daripada model struktur. Bagi keduadua peringkat ini, empat prosedur di dalam SmartPLS 3 diguna pakai iaitu PLS algorithm, bootstrapping, blindfolding dan PLS predict.

Kesemua pemboleh ubah dalam kajian ini dimodelkan menggunakan pengukuran reflektif dan empat kriteria penilaian model digunakan dalam menentukan kebolehpercayaan dan kesahan model pengukuran Hair et al. (2017). Pertama, bebanan indikator perlu melebihi 0.708 bagi menunjukkan bahawa lebih daripada 50 peratus varians indikator diterangkan oleh konstruk yang dikaitkan dengannya. Kedua, kebolehpercayaan konsisten dalaman diukur menggunakan kaedah kebolehpercayaan komposit dan Cornbach's alpha yang mana kedua-dua kaedah ini perlu mempunyai nilai 0.70 ke atas. Ketiga, kesahan konvergen diukur dengan melihat kepada nilai purata varians yang diekstrak (AVE). Nilai yang dicadangkan adalah 0.50 bagi menunjukkan bahawa konstruk menerangkan sekurang-kurangnya 50 peratus varians dalam kesemua item yang dikaitkan dengannya. Kriteria terakhir adalah kesahan divergen yang merujuk kepada sejauh mana konstruk kajian berbeza secara empirikal daripada konstruk lain yang dikaji dalam model kajian. Meskipun kaedah Fornell-Lacrker telah digunakan sejak bertahun lamanya, Henseler et al. (2015) mencadangkan agar kriteria nisbah korelasi heterotrait-monotrait (HTMT) diguna pakai dalam menentukan kesahan divergen. Tahap penentuan adalah bersandarkan kepada nilai 0.85 atau nilai 0.90 . Nilai 0.85 dipilih jika konseptualisasi kontstruk dapat ditentukan ianya adalah berbeza.

Penilaian seterusnya adalah pada model struktur di mana hipotesis kajian diuji dengan menggunakan hasil penganggaran yang diperolehi daripada ujian model pengukuran. Model struktur dinilai dengan menganalisis koefisien alur dan nilai-t untuk menentukan signifikan hubungan antara pemboleh ubah tidak bersandar dengan pemboleh ubah bersandar. Namun, pengkaji disarankan untuk menilai variance inflation factor (VIF) terlebih dahulu bagi memastikan tiada masalah kolineariti wujud pada model struktur. Seterusnya, penilaian dibuat bagi menentukan coefficient of determination atau $R^{2}$. Selain itu, saiz kesan $\left(f^{2}\right)$ dan perkaitan ramalan $\left(Q^{2}\right)$ turut diuji.
Saiz kesan merujuk kepada nilai saiz kesan pemboleh ubah peramal ke atas pemboleh ubah bersandar sama ada kecil (0.02) sederhana (0.15) atau besar (0.35) (Henseler et al. 2009). Perkaitan ramalan pula digunakan untuk mengukur keupayaan model dalam meramalkan penunjuk bagi setiap pemboleh ubah laten endogenous (Hair et al. 2011). Perkaitan ramalan boleh diukur dengan kriteria Stone-Geisser dimana menurut Tenenhaus et al. (2005), analisis blindfolding di dalam perisian SmartPLS boleh diguna untuk mendapatkan ukuran tersebut. Walau bagaimanapun, kebanyakan penyelidik telah beralih kepada pelaporan PLS predict yang diperkenalkan oleh Shmueli et al. (2019). Kaedah blindfolding tidak tepat untuk menggambarkan keupayaan model untuk tujuan ramalan memandangkan pengujiannya adalah berdasarkan kepada satu titik data yang disingkirkan dan diandaikan (Sarstedt et al. 2017). Mankala, PLS predict berupaya menganalisis kuasa ramalan model dengan lebih baik berbanding dengan perkaitan ramalan StoneGeisser kerana ia membahagikan sampel sedia ada kepada sampel latihan (training sample) yang bertujuan untuk menghasilkan anggaran parameter dan sampel penahan (holdout sample) yang digunakan untuk menentukan keupayaan model ramalan berdasarkan kepada anggaran parameter yang telah disediakan (Shmueli et al. 2019).

\section{HASIL KAJIAN}

\section{HASIL ANALISIS MODEL PENGUKURAN}

Jadual di Lampiran A menunjukkan hasil dapatan bagi model pengukuran reflektif untuk ketiga-tiga konstruk kajian. Penilaian model pengukuran menggunakan kaedah biasa dilakukan bagi konstruk karakteristik kerja Milenial dan tingkah laku inovatif pekerja. Manakala, penggunaan media sosial di tempat kerja dinilai menggunakan kaedah konstruk tertib tinggi (higher order construct) seperti yang disarankan oleh Sarstedt et al. (2019).

Julat beban indikator bagi karateristik kerja Milenial adalah antara 0.608 hingga 0.816 , manakala untuk tingkah laku inovatif pekerja Milenial pula adalah antara 0.607 hingga 0.845 . Walaupun terdapat nilai beban indikator di bawah paras penerimaan 0.708, indikator tersebut dikekalkan di dalam model kerana nilai kebolehpercayaan konsisten dalaman bagi keduadua konstruk ini melebihi paras 0.70. Nilai Cronbach's alpha adalah 0.827 (karakteristik kerja Milenial) dan 0.901 (tingkah laku inovatif pekerja), manakala nilai kebolehpercayaan komposit pula adalah 0.874 (karakteristik kerja Milenial) dan 0.919 (tingkah laku inovatif pekerja). Bertepatan dengan saranan Hair et al. (2011) bahawa indikator yang mempunyai nilai di bawah 0.70 hanya perlu dipertimbangkan untuk dikeluarkan daripada model hanya jika proses ini meningkatkan nilai kebolehpercayaan komposit melebihi paras 0.70. Oleh kerana tiada isu tersebut pada nilai kebolehpercayaan 
komposit, maka indikator tersebut dikekalkan. Bagi konstruk penggunaan media sosial di tempat kerja, kebergunaan mempunyai julat nilai indikator antara 0.562 hingga 0.871 , manakala kesemua indikator mudah guna mempunyai nilai melepasi paras 0.70 . Nilai indikator yang rendah tidak disingkirkan kerana nilai kebolehpercayaan komposit bagi kebolehgunaan adalah 0.912. Pada tertib tinggi, penggunaan media sosial di tempat kerja mempunyai nilai indikator melepasi paras 0.70 , dan nilai kebolehpercayaan konsisten dalaman pula adalah 0.657 (Cronbach's alpha) dan 0.844 (kebolehpercayaan komposit).

Seterusnya, penilaian dibuat bagi mengenal pasti kesahan konvergen dan divergen. Kesemua konstruk kajian, termasuk konstruk kebergunaan media sosial di tempat kerja pada tertib tinggi, melepasi 0.50 . Ini bermaksud setiap konstruk berkenaan berupaya menerangkan lebih daripada 50 peratus varians di dalam indikator yang dikaitkan dengannya.

Begitu juga dengan kesahan divergen seperti yang ditunjukkan di dalam Jadual 1. Nilai HTMT ${ }_{0.85}$ menunjukkan julat antara 0.119 hingga 0.561 bagi penilaian konstruk tertib rendah. Bagi penilaian konstruk tertib tinggi pula, nilai $\mathrm{HTMT}_{085}$ adalah antara 0.348 hingga 0.590. Ini bermaksud konstruk kajian adalah berbeza secara empirikal.

\section{HASIL ANALISIS MODEL STRUKTUR}

Setelah model pengukuran dibuktikan mempunyai kebolehpercayaan dan kesahan yang diterima, analisis seterusnya melibatkan penilaian model struktur. Nilai VIF bagi penggunaan media sosial di tempat kerja, karakteristik kerja Milenial, dan tingkah laku inovatif pekerja adalah di bawah aras 5, iaitu antara 1.000 hingga 1.258. Ini bermaksud tiada masalah kolineariti dikenal pasti pada pemboleh ubah peramal di dalam model laluan PLS ini. Manakala nilai min yang diperolehi untuk kesemua pemboleh ubah adalah melebihi nilai 4.0 iaitu nilai min 4.26 adalah untuk penggunaan media sosial, 4.19 untuk karakteristik kerja Milenial dan 4.10 untuk tingkah laku inovatif pekerja.
Rajah 1 menunjukkan nilai koefisien alur, nilai- $t$, dan nilai coefficient of determination $\left(R^{2}\right)$. Koefisien alur bagi kesemua hubungan yang dihipotesiskan adalah signifikan. $\mathrm{H}_{1}$ yang menyatakan bahawa terdapat hubungan yang positif antara penggunaan media sosial di tempat kerja dan tingkah laku inovatif pekerja adalah disokong ( $\beta=$ 0.196 , nilai- $t=2.431$ ). Penggunaan media sosial di tempat kerja juga mempunyai hubungan yang positif dengan karakteristik kerja Milenial ( $\beta=0.453$, nilai- $t=7.292)$ di mana $\mathrm{H}_{2}$ adalah disokong. Begitu juga karakteristik kerja Milenial mempunyai hubungan yang positif dengan tingkah laku inovatif pekerja $(\beta=0.256$, nilai- $\mathrm{t}=3.221)$ dan menyokong $\mathrm{H}_{3}$. Seterusnya, kajian ini menguji kesan pengantara karakteristik kerja Milenial terhadap penggunaan media sosial dan tingkah laku inovatif pekerja. $\mathrm{H}_{4}$ yang menyatakan karakteristik kerja Milenial bertindak sebagai pengantara hubungan antara penggunaan media sosial dan tingkah laku inovatif pekerja turut disokong. Hubungan tidak langsung juga menyokong hipotesis pengantara separa dengan alur koefisien, $\beta=0.116$ (nilai- $t$ = 2.962) (Jadual 2). Berdasarkan kepada saranan Zhao et al. (2010), jenis pengantara di dalam model ini adalah pengantara pelengkap. Ianya disebabkan kedua-dua hubungan langsung dan tidak langsung adalah signifikan dan arah alur adalah positif

Jumlah varians di dalam konstruk tingkah laku inovatif pekerja Milenial yang diterangkan oleh penggunaan media sosial di tempat kerja dan karakteristik kerja Milenial adalah 14.9 peratus $\left(R^{2}=\right.$ 0.149). Bagi konstruk karakteristik kerja Milennial pula, jumlah varians yang diterangkan oleh penggunaan media sosial di tempat kerja adalah lebih besar berbanding jumlah varians di dalam konstruk tingkah laku inovatif pekerja Milenial, iaitu 20.5 peratus $\left(R^{2}=0.205\right)$. Saiz kesan penggunaan media sosial di tempat kerja adalah sederhana terhadap karakteristik kerja Milennial $\left(f^{2}=\right.$ 0.258 ) manakala saiz kesan yang kecil dikenal pasti bagi kesan penggunaan media sosial di tempat kerja terhadap tingkah laku inovatif pekerja Milenial $\left(f^{2}=0.036\right)$. Saiz kesan karakteristik kerja Milenial terhadap tingkah laku inovatif pekerja Milenial juga adalah kecil, iaitu $f^{2}=$ 0.061

JADUAL 1. Kesahan divergen

\begin{tabular}{|c|c|c|c|}
\hline Konstruk tertib bawah & Karakteristik Kerja Millenial & Kebergunaan & Mudah guna \\
\hline \multicolumn{4}{|l|}{ Karakteristik Kerja Millenial } \\
\hline Kebergunaan & 0.498 & & \\
\hline Mudah guna & 0.374 & 0.561 & \\
\hline Tingkahlaku Inovatif Pekerja & 0.369 & 0.407 & 0.119 \\
\hline Konstruk tertib tinggi & Karakteristik Kerja Millenial & Penggunaan Media Sosial & \\
\hline \multicolumn{4}{|l|}{ Karakteristik Kerja Millenial } \\
\hline Penggunaan Media Sosial & 0.590 & & \\
\hline Tingkahlaku Inovatif Pekerja & 0.369 & 0.348 & \\
\hline
\end{tabular}


Penilaian terakhir pada model struktur di buat untuk mengenal pasti kebolehramalan model yang dicadangkan, atau dikenali sebagai perkaitan ramalan. Dapatan prosedur blindfolding menunjukkan nilai Stone-Geisser $Q^{2}$ adalah melebihi 0 , iaitu $Q^{2}=0.104$ (karakteristik kerja Milenial) dan $Q^{2}=0.104$ (tingkah laku inovatif pekerja). Nilai melebihi 0 juga diperolehi bagi perkaitan ramalan yang diuji menggunakan prosedur PLS predict. Bagi karakteristik kerja Milenial, nilai $Q_{\text {PLSpredict }}^{2}$ adalah 0.185 , manakala bagi tingkah laku inovatif pekerja pula nilai $Q_{\text {PLSpredict }}^{2}$ yang diperolehi adalah 0.068. Dengan itu, dapat disimpulkan bahawa model kajian ini mempunyai perkaitan ramalan yang baik.

\section{PERBINCANGAN DAN KESIMPULAN}

Tingkah laku inovatif pekerja dalam kalangan Milenial merupakan tenaga penggerak utama kepada peningkatan inovasi supaya organisasi terus bertahan mendepani cabaran perubahan persekitaran perniagaan yang dinamik (Korzilius et al. 2017). Sehubungan dengan itu, tujuan kajian ini adalah untuk menguji sama ada penggunaan media sosial di tempat kerja mampu mendorong tingkah laku inovatif pekerja dalam kalangan Milenial. Seterusnya kajian ini menguji karakteristik kerja Milenial sebagai pengantara hubungan tersebut di samping menguji hubungan langsung antara penggunaan media sosial dengan karakteristik kerja dan karakteristik kerja dengan tingkah laku inovatif pekerja.

Kajian ini dapat menambahkan beberapa bukti empirikal kepada badan pengetahuan. Pertama, hasil kajian membuktikan terdapat hubungan yang positif dan signifikan antara penggunaan media sosial di tempat kerja dan tingkah laku inovatif pekerja, $\mathrm{H}_{1}$ adalah disokong. Hasil kajian ini secara umunya adalah konsisten dengan beberapa kajian terdahulu yang mendapati penggunaan media sosial di tempat kerja memupuk sikap dan tingkah laku positif seperti meningkatkan prestasi kerja dan produktiviti pekerja (Cao \& Ali 2018; Chu 2020; Crammond et al. 2018; Men et al. 2020). Manakala, kajian terdahulu berkaitan tingkah laku inovatif mendapati beberapa faktor individual dan faktor kontekstual merupakan faktor yang mendorong tingkah laku inovatif pekerja (Hou 2017; Iqbal et al. 2020; Thurlings et al. 2014; Wang \& Zhu 2018), Kajian ini pula telah membuktikan secara empirikal bahawa faktor teknologi iaitu penggunaan media sosial mampu mendorong tingkah laku inovatif dalam kalangan Milenial. Ia turut mengesahkan perkaitan yang didasari oleh TAM iaitu persepsi kebergunaan dan mudah guna media sosial menghasilkan hubungan yang signifikan dengan tingkah laku yang positif (Matikiti et al. 2018). Berbeza pula dengan kajian yang dijalankan oleh Han dan Xia (2020) yang mendapati hubungan antara penggunaan media sosial dan tingkah laku inovatif adalah tidak signifikan tetapi suara pekerja adalah pengantara penuh kepada hubungan tersebut. Perbezaan diantara keduadua hasil kajian adalah disebabkan oleh responden kajian yang berbeza di mana kajian ini secara khususnya memfokuskan kepada Milenial memandangkan mereka ini adalah golongan yang celik teknologi (Zelga 2018).

Kedua, Milenial yang dibesarkan dalam kepesatan teknologi telah memupuk kecenderungan mereka dalam penggunaan media sosial dan mencipta karakteristik kerja yang unik berbanding generasi sebelumnya (Twenge 2010). Ini telah mengukuhkan lagi hasil kajian yang diperoleh iaitu terdapat hubungan yang positif di antara penggunaan media sosial dan karakteristik kerja Milenial, di mana $\mathrm{H}_{2}$ adalah disokong. Hasil kajian ini turut disokong oleh beberapa kajian lepas seperti penggunaan media sosial telah menggalakkan Milenial untuk melakukan pelbagai tugasan yang kompleks dan mencabar (Wang \& Zhu 2018), memudahkan mereka mendapat maklum balas pihak pengurusan untuk penambahbaikan kerja (Bogosian \& Rousseau 2017) dan mewujudkan persekitaran kerja yang fleksibel (Bannon et al. 2011). Implikasi ketiga, hasil kajian ini turut menyokong Hipotesis 3 iaitu terdapat hubungan yang positif antara karakteristik kerja dan tingkah laku inovatif pekerja. Ia adalah konsisten dengan beberapa kajian lepas di mana secara umumnya karakteristik kerja berjaya membuahkan hasil kerja yang positif (De Varo \& Brookshire 2007; Vui-Yee \& Paggy 2018). Karakteristik kerja juga dapat memupuk kreativiti pekerja apabila melaksanakan kerja yang kompleks dan mencabar serta dapat menggunakan pelbagai kemahiran kerja (Kurz et al. 2018; Wang \& Zhu 2018). Menurut Amabile et al. (1996), pekerja yang kreatif adalah cenderung untuk menghasilkan sesuatu yang inovatif.

Hasil kajian seterusnya juga telah menambahkan bukti empirikal yang keempat kepada badan pengetahuan dengan membuktikan karakteristik kerja Milenial bertindak sebagai pengantara separa hubungan antara penggunaan media sosial dan tingkah laku inovatif pekerja, Hipotesis 4 adalah disokong. Hasil kajian ini adalah konsisten dengan kajian Han dan Xia (2020) di mana suara pekerja adalah pengantara penuh hubungan antara penggunaan media sosial dan tingkah laku pekerja. Selain itu, kajian terdahulu juga mendapati hubungan antara pemboleh ubah tidak bersandar dan tingkah laku inovatif pekerja turut dikukuhkan dengan kehadiran faktor psikologi sebagai pemboleh ubah penyederhana dan pengantara (Fang et al. 2019; Iqbal et al. 2020). Justeru, hasil kajian ini telah menunjukkan karakteristik kerja merupakan mekanisme tambahan yang boleh mengukuhkan hubungan di antara pemboleh ubah tidak bersandar dengan tingkah laku inovatif pekerja.

Di samping menyumbang kepada badan pengetahuan, hasil kajian ini juga mempunyai beberapa implikasi praktikal untuk meningkatkan kepekaan pihak pengurusan organisasi dengan corak pengurusan kerja Milenial yang seiring dengan perkembangan teknologi. Pertama, organisasi perlu memperluaskan penggunaan media sosial berorientasikan kerja kerana ia terbukti dapat 
JADUAL 2. Kesan langsung dan kesan tidak langsung

\begin{tabular}{llllll}
\hline & Kesan Langsung & $95 \%$ sela keyakinan kesan langsung & Nilai t & Signifikan $(\mathrm{p}<0.05)$ & Jenis Pengantara \\
\hline PMS $\rightarrow$ TIP & 0.196 & $\{0.036,0.352\}$ & 2.431 & Ya & Pelengkap \\
\hline \hline & Kesan Tidak Langsung & $95 \%$ sela keyakinan kesan langsung & Nilai t & Signifikan $(\mathrm{p}<0.05)$ & Jenis Pengantara \\
\hline PMS $\rightarrow$ TIP & 0.116 & $\{0.047,0.201\}$ & 2.962 & Ya & Pelengkap \\
\hline
\end{tabular}

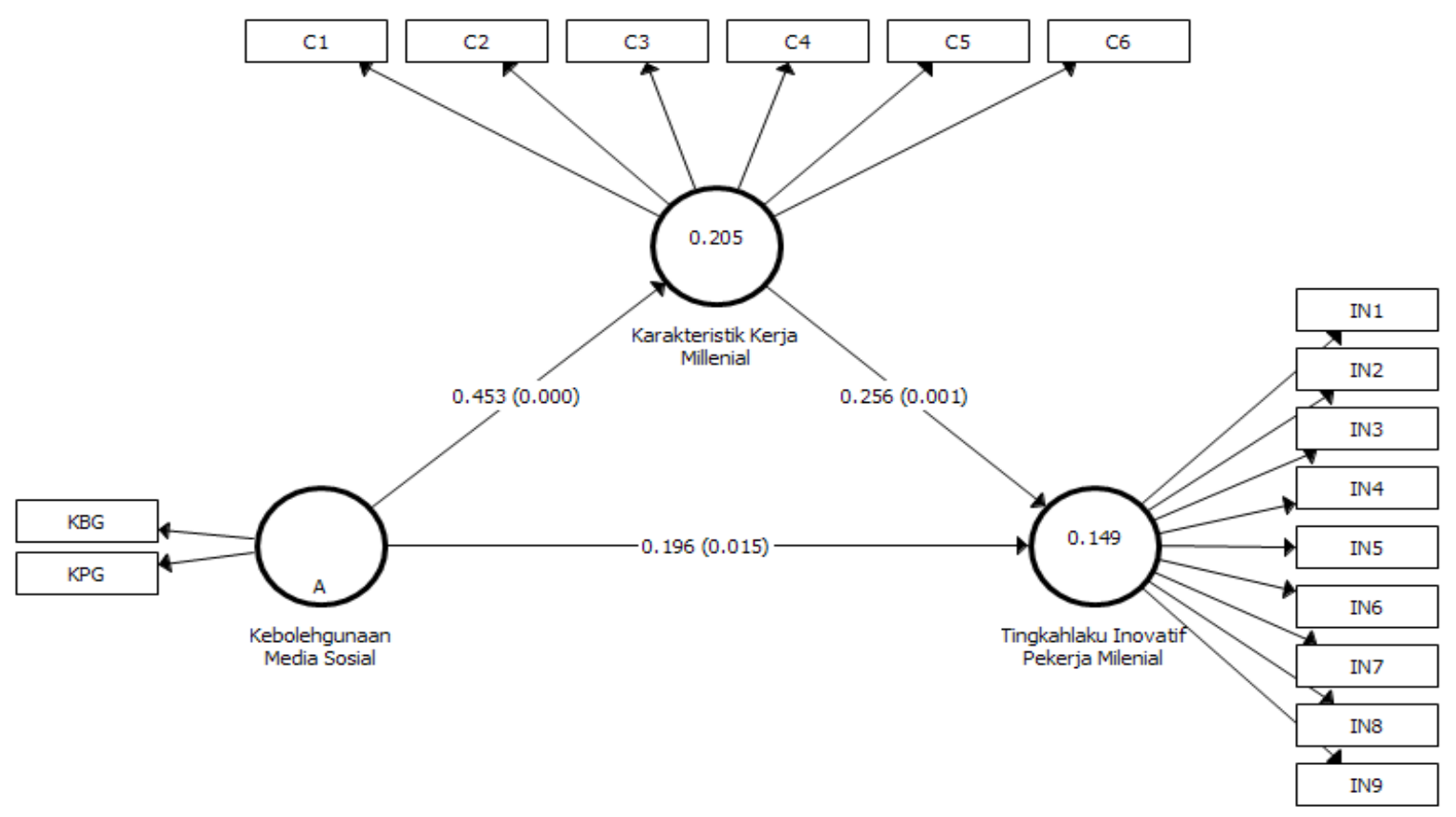

RAJAH 1. Nilai koefisien alur, nilai-t, dan nilai coefficient of determination $\left(R^{2}\right)$

menghasilkan pelbagai manfaat bukan sahaja kepada pencapaian organisasi tetapi juga dapat memotivasikan pekerja untuk membentuk sikap dan tingkah laku yang lebih positif (Men et al. 2020) seperti tingkah laku inovatif. Kedua, walaupun Milenial telah mula mendominasi dunia pekerjaan tetapi mereka masih di peringkat awal dan sedang dalam proses membangunkan kemahiran berkaitan dengan kerja (Jamrog 2002). Bersesuaian dengan karakteriskik kerja mereka, organisasi harus membangunkan beberapa strategi yang dapat menyuntik minat terhadap kerja supaya lebih proaktif dalam mengilhamkan idea yang kreatif dan inovatif. Antara strateginya ialah merancangkan susunan kerja yang fleksibel, memberi tugasan yang mencabar, menyediakan latihan untuk pembangunan kemahiran dan memberi maklum balas untuk penambahbaikan kerja (Farell \& Hurt 2014; Zelga 2018).

Kajian ini juga mempunyai beberapa limitasi yang membuka ruang untuk kajian masa hadapan. Pertama, walaupun kajian ini memfokuskan kepada responden dalam kalangan Milenial, tetapi tidak mengkhususkan kepada jawatan tertentu yang berkemungkinan menyebabkan saiz kesan $\left(f^{2}\right)$ pemboleh ubah dalam kajian ini adalah kecil. Secara rasionalnya, penggunaan media sosial yang berorientasikan kerja banyak melibatkan penyelesaian masalah dan pembuatan keputusan di mana ia dilaksanakan oleh pekerja mengikut autonomi dan jawatan dalam organisasi (Farooq et al. 2019). Kajian masa hadapan boleh mengkhususkan kepada golongan eksekutif bagi mengukuhkan lagi hasil kajian. Kedua, kajian ini hanya memfokuskan kepada karakteristik kerja Milenial sebagai pengantara hubungan di antara penggunaan media sosial dan tingkah laku inovatif di tempat kerja. Terdapat pelbagai faktor individual dan faktor kontekstual yang boleh diuji sebagai mekanisme asas sama ada sebagai pengantara atau penyederhana yang dapat mengembangkan lagi pemahaman mengenai pengaruh penggunaan media sosial ke atas tingkah laku inovatif pekerja. Oleh itu, kajian masa hadapan boleh memperluaskan model kajian dengan mengambil kira faktor seperti kesediaan teknologi, latihan, sokongan pengurusan, personaliti dan sebagainya mengikut justifikasi kajian lepas. Ketiga, hasil kajian menunjukkan jumlah varians di dalam konstruk tingkah laku inovatif pekerja Milenial yang diterangkan oleh penggunaan media sosial di tempat kerja dan karakteristik kerja Milenial adalah 14.9 peratus $\left(R^{2}=0.149\right)$, yang sangat kecil. Hanya kerana nilainya kecil tidak bermakna 
model ini tidak bagus atau tidak berguna (Moksony 1999) terutamanya dalam menjelaskan tingkah laku manusia. Nilai $\mathrm{R}^{2}$ yang kecil sekalipun boleh menjadi sangat bermakna kerana ia adalah mengenai kekuatan penjelasan dan bukan pengukuhan model (Baguley 2009). Berkemungkinan terdapat beberapa prediktor lain yang boleh digabungkan dalam membantu menjelaskan pemboleh ubah bersandar (Lukacs et al. 2010) seperti faktor individual, kontekstual dan teknologi.

Kesimpulannya, kajian ini telah membuktikan secara empirikal bahawa penggunaan media sosial dapat mendorong Milenial untuk membentuk tingkah laku inovatif dalam organisasi. Kajian ini memfokuskan kepada Milenial kerana mereka sedang mendominasi dunia pekerjaan dan membangun seiring dengan perkembangan teknologi. Milenial banyak bergantung kepada penggunaan media sosial dalam kehidupan dan pekerjaan mereka. Keberadaan Milenial dalam organisasi telah merancakkan penggunaan media sosial berorientasikan kerja yang bukan sahaja dapat menyumbang kepada peningkatan tingkah laku yang positif tetapi juga kecekapan organisasi dalam mendepani persekitaran perniagaan yang dinamik. Kajian ini turut membuktikan karakteristik Milenial yang berbeza dengan generasi sebelumnya berjaya menyuntik motivasi dalaman untuk mereka mencapai hasil kerja yang positif.

\section{RUJUKAN}

Agarwal, U.A. 2014. Examining the impact of social exchange relationships on innovative work behaviour. Team Performance Management: An International Journal 20(3/4): 102-120.

Akram, T., Lei, S., Haider, M. J. \& Hussain, S.T. 2018. Exploring the impact of knowledge sharing on the innovative work behavior of employees: A study in China. International Business Research 11(3): 186-194.

Alalwan, A.A., Rana, N.P., Dwivedi, Y.K. \& Algharabat, R. 2017. Social media in marketing: A review and analysis of the existing literature. Telematics and Informatics 34(7): 1177-1190.

Ali-Hassan, H., Nevo, D. \& Wade, M. 2015. Linking dimensions of social media use to job performance: The role of social capital. The Journal of Strategic Information Systems 24(2): 65-89.

Amabile, T.M. 1988. A model of creativity and innovation in organizations. Research in Organizational Behaviour 10: 123-167.

Amabile, T.M. 1996. Creativity in Context. Boulder, C.O.:Westview,

Axtell, C.M., Holman, D.J., Unsworth, K.L., Wall, T.D. \& Waterson, P.E. 2000. Shopfloor innovation: Facilitating the suggestion and implementation of ideas. Journal of Occupational and Organizational Psychology 73(3): 265-285.

Badri, S.K.Z., Mung, C.T.Y. \& Ramos, H.M. 2020. Work passion and psychological wellbeing among millennial employees in Malaysia: The moderating role of personality. International Journal of Employment Studies 28(1): $28-47$
Baguley, T. 2009. Standardized or simple effect size: What should be reported? British Journal of Psychology 100: 603-617.

Bannon, S., Ford, K. \& Meltzer, L. 2011. Understanding millennials in the workplace. The CPA Journal 81(11): 61.

Birdi, K., Leach, D., \& Magadley, W. 2014. The relationship of individual capabilities and environmental support with different facets of designers' innovative behaviour. Journal of Product Innovation Management 33(1): 19-35.

Bogosian, D. \& Rousseau, C. 2017. How and why Millennials are shaking up organizational cultures. Rutgers Business Review 2(3): 386-394

Bolton, R.N., Parasuraman, A., Hoefnagels, A., Migchels, N., Kabadayi, S., Gruber, T., Komarova L.Y. \& Solnet, D. 2013. Understanding Generation Y and their use of social media: a review and research agenda. Journal of Service Management 24(3): 245-267.

Bysted, R. \& Hansen, J. 2015. Comparing public and private sector employees' innovative behaviour. Public Management Review 17(5): 698-717.

Cao, X. \& Ali, A. 2018. Enhancing team creative performance through social media and transactive memory system. International Journal of Information Management 39: 6979.

Cekada, T.L. 2012. Training a multigenerational workforce: Understanding key needs \& learning styles. Professional Safety 57(03): 40-44.

Cekmecelioglu, H.G. \& Ozbag, G.K. 2016. Psychological empowerment and support for innovation in Turkish manufacturing industry: Relations with individual creativity and firm innovativeness. Journal for East European Management Studies 21 (1): 1-10.

Çetinkaya, A.S. \& Rashid, M. 2018. The effect of social media on employees' job performance: The mediating role of organizational structure. Journal of Organizational Psychology 18(4): 94-116.

Chen, G., Farh, J.L., Campbell, E.M., Wu, Z. \& Wu, X. 2013. Teams as innovative systems: Multilevel motivational antecedents of innovation in R\&D teams. Journal of Applied Psychology 98: 1018-1027.

Chu, T.H. 2020. A meta-analytic review of the relationship between social media use and employee outcomes. Telematics Inform 50: 101379.

Crant J.M. 2000. Proactive organizational behavior. Journal of Management 26: 453-462.

Crammond, R., Omeihe, K.O., Murray, A. \& Ledger, K. 2018. Managing knowledge through social media: Modelling an entrepreneurial approach for Scottish SMEs and beyond. Baltic Journal of Management 13(3): 303-328

Davis, F.D. 1989. Perceived usefulness, perceived ease of use and user acceptance of information technology. MIS Quarterly 13(2): 319-340.

Deal, J. J., Altman, D.G., \& Rogelberg, S.G. 2010. Millennials at work: What we know and what we need to do (if anything). Journal of Business and Psychology 25(2): 191-199.

De Spiegelaere, S., Van Gyes, G. \& Van Hootegem, G. 2016. Not all autonomy is the same. different dimensions of job autonomy and their relation to work engagement \& innovative work behavior. Human Factors and Ergonomics in Manufacturing 26(4): 515-527.

DeVaro, J., Li, R. \& Brookshire, D. 2007. Analysing the job characteristics model: New support from a cross-section 
of establishments. The International Journal of Human Resource Management 18(6): 986-1003

Donelan, H. 2016. Social media for professional development and networking opportunities in academia. Journal of Further and Higher Education 40(5): 706-729.

Ewing, M., Men, L. R. \& O’Neil, J. 2019. Using social media to engage employees: Insights from internal communication managers. International Journal of Strategic Communication 13(2): 110-132

Fang, Y., Chen, J., Wang, M. \& Chen, C. 2019. The impact of inclusive leadership on employees' innovative behaviors: The mediation of psychological capital. Frontiers in Psychology 10: 1-11.

Farooq, O., Farooq, M. \& Reynaud, E. 2019. Does employees' participation in decision making increase the level of corporate social and environmental sustainability? An investigation in South Asia. Sustainability 11: 511.

Ferreira, D.S.B. 2019. Building trust from the inside out: Employees and their power of influence. In Strategic Employee Communication, edited by G. Thornton, V. Mansi, B. Carramenha, \& T. Cappellano. Cham: Palgrave Macmillan.

Farrell, L. \& Hurt, A.C. 2014. Training the Millennial generation: Implications for organizational climate. $E$ Journal of Organizational Learning \& Leadership 12(1): 47-60.

Garlick R \& Langley K. 2007. Reaching Gen Y on both sides of the cash register. Retail Issues Letter 18(2): 1-6.

Green, S.B. 1991. How many subjects does it take to do a regression analysis? Multivariate Behavioral Research 26: 499-510.

Grošelj, M., Černe, M., Penger, S. \& Grah, B. 2020. Authentic and transformational leadership and innovative work behaviour: the moderating role of psychological empowerment. European Journal of Innovation Management 24(3): 677-706.

Gulyani, G. \& Bhatnagar, J. 2017. Mediator analysis of passion for work in Indian millennials: relationship between protean career attitude and proactive work behavior Career Development International 22(1): 50-69.

Hackman, J.R. \& Oldham, G.R. 1976. Motivation through the design of work: Test of a theory. Organizational Behavior and Human Performance 16: $250-279$.

Hair Jr, J. F., Sarstedt, M., Ringle, C.M. \& Gudergan, S.P. 2017. Advanced Issues in Partial Least Squares Structural Equation Modeling. 2nd ed. Thousand Oaks, CA: Sage Publications.

Hair, J. F., Ringle, C. M. \& Sarstedt, M. 2011. PLS-SEM: Indeed a silver bullet. Journal of Marketing Theory and Practice 19(2): 139-152.

Hamid, R.A., Ismail, M.D. \& Ismail I.R. 2020. Importance of employee participation in lean thinking and their competency towards employee innovative behaviour. The South East Asian Journal of Management 14(1): 23-43

Hammond, M.M., Neff, N.L., Farr, J.L., Schwall, A.R. \& Zhao, X. 2011. Predictors of individual-level innovation at work: A meta-analysis. Psychology of Aesthetics, Creativity, \& The Arts 5(1): 90-105.

Han, Q. \& Xia, L. 2020. Social media use and employee innovative behavior: The mediating role of employee voice. Social Behavior and Personality: An International Journal 48(3): e9014.

Henseler, J., Ringle, C.M. \& Sarstedt, M. 2015. A new criterion for assessing discriminant validity in variance-based structural equation modeling. Journal of the Academy of Marketing Science 43(1): 115-135.

Henseler, J., Ringle, C.M. \& Sinkovics, R.R. 2009. The use of partial least squares path modeling in international marketing. Advances in International Marketing 20: 277319.

Holman, D. J., Axtell, C.M., Sprigg, C.A., Totterdell, P. \& Wall, T.D. 2010. The mediating role of job characteristics in job redesign interventions: A serendipitous quasi-experiment. Journal of Organizational Behavior 31: 84-105.

Hou, X., Li, W. \& Yuan, Q 2018. Frontline disruptive leadership and new generation employees' innovative behaviour in China: the moderating role of emotional intelligence. Asia Pacific Business Review 24(4): 459-471.

Hou, X.F. 2017. Multilevel influence of destructive leadership on Millennial generation employees' innovative behaviour. Social Behaviour and Personality: An International Journal 45 (7): 1113-1126.

Hu, S., Gu, J., Liu, H. \& Huang, Q. 2017. The moderating role of social media usage in the relationship among multicultural experiences, cultural intelligence, and individual creativity. Information Technology \& People 30(2): 265-281.

Humphrey, S.E., Nahrgang, J.D. \& Morgeson, F.P. 2007. Integrating motivational, social, and contextual work design features: A meta-analytic summary and theoretical extension of the work design literature. Journal of Applied Psychology 92(5): 1332-1356

Iqbal, A., Latif, K.F. \& Ahmad, M.S. 2020. Servant leadership and employee innovative behaviour: exploring psychological pathways. Leadership \& Organization Development Journal 41(6): 813-827.

Istanbulluoglu, D. 2017. Complaint handling on social media: The impact of multiple response times on consumer satisfaction. Computers in Human Behavior 74: 72-82.

Jamrog, J. J. 2002. The coming decade of the employee. Human Resource Planning 25: 5-11

Janssen, O. 2000. Job demands, perceptions of effort-reward fairness and innovative work behaviour. Journal of Occupational and organizational psychology 73(3): 287302.

Jena, L.K. \& Memon, N.Z. 2018. Does workplace flexibility usher innovation? A moderated mediation model on the enablers of innovative workplace behavior. Global Journal of Flexible Systems Management 19(1): 5-17.

Judge, T.A., Bono, J.E. \& Locke, E.A. 2000. Personality and job satisfaction: The mediating role of job characteristic. Journal of Applied Psychology 85(2): 237-249.

Kim, H., Knight, D.K. \& Crutsinger, C. 2009. Generation Y employees' retail work experience: The mediating effect of job characteristics. Journal of Business Research 62: 548-556.

Korzilius, H., Bücker, J.J. \& Beerlage, S. 2017. Multiculturalism and innovative work behavior: The mediating role of cultural intelligence. International Journal of Intercultural Relations 56: 13-24.

Kurz V, Hüsig S \& Dowling M. 2018. What drives different employee types of innovative behaviour? Development and test of an integrative model of employee driven innovation in German firms. International Journal of Entrepreneurship and Innovation Management 22(4-5): 397-426.

Landers, R. N. \& Schmidt, G.B. 2016. Social Media in Employee Selection and Recruitment. Theory, Practice, 
and Current Challenges. Cham: Springer International Publishing AG.

Leonardi, P., Huysman, M. \& Steinfield, C.W. 2013. Enterprise social media: Definition, history, and prospects for the study of social technologies in organizations. Journal of Computer-Mediated Communication 19(1): 1-31

Lin, F., Fofanah, S.S. \& Liang, D. 2011. Assessing citizen adoption of e-Government initiatives in Gambia: A validation of the technology acceptance model in information systems success. Government Information Quarterly 28(2): 271-279.

Lukacs, P.M., Burnham, K.P. \& Anderson, D.R. 2010. Model selection bias and Freedman's paradox. Ann Inst Stat Math 62:117-125.

Lyons, S., \& Kuron, L. 2014. Generational differences in the workplace: A review of the evidence and directions for future research. Journal of Organizational Behavior 35(S1): S139-S157

Malaysian Communications and Multimedia Commission (MCMC) 2020. Internet Users Survey 2020.

Marangunić, N. \& Granić, A. 2015. Technology acceptance model: A literature review from 1986 to 2013. Universal Access in the Information Society 14(1): 81-95.

Marin-Garcia, J.A., Aznar-Mas, L.E. \& González-Ladrón de Guevara, F. 2011. Innovation types and talent management for innovation. Working Papers on Operations Management, 2(2), 25-31.

Markova, S. \& Petkovska-Mirčevska, T. 2013. Social media and supply chain. Amfiteatru Economic XV(33): 89-102.

Matikiti, R., Mpinganjira, M. \& Roberts-Lombard, M. 2018. Application of the Technology Acceptance Model and the Technology-Organisation-Environment Model to examine social media marketing use in the South African tourism industry. South African Journal of Information Management 20(1): 1-12.

Meik J., Brock C. \& Blut M. 2014. Complaining Customers as Innovation Contributors: Stimulating Service Innovation through Multichannel Complaint Management. In: Proceedings of SRII Global Conference 2014, 125-132.

Men, L. R., O’Neil, J. \& Ewing, M. 2020. Examining the effects of internal social media usage on employee engagement. Public Relations Review 101880.

Moksony, F. 1999. Small is beautiful. The use and interpretation of $\mathrm{R}^{2}$ in social research. Review of Sociology (Special issue): 130-138.

Mutonyi, B.R., Slåtten, T. \& Lien, G. 2020. Empowering leadership, work group cohesiveness, individual learning orientation and individual innovative behaviour in the public sector: empirical evidence from Norway. International Journal of Public Leadership 16(2): 175197.

Parzefall, M.R., Seeck, H. \& Leppänen, A. 2008. Employee innovativeness in organizations: A review of the antecedents. Finnish Journal of Business 2(8): 165-182.

Piccolo, R.F. \& Colquitt, J.A. 2006. Transformational leadership and job behaviors: The mediating role of core job characteristics. Academy of Management Journal 49(2): 327-340.

Pieters, R. 2017. Meaningful mediation analysis: Plausible causal inference and informative communication. Journal of Consumer Research 44(3): 692-716.

Pudliner, B.A., Brey, E.T. \& Choi, H. G. 2015. The emergence of social media: A research narrative review. Society for Marketing Advances Proceedings.
Ringle, C.M., Wende, S. \& Becker, J.M. 2015. SmartPLS 3. Boenningstedt: SmartPLS GmbH. Available at http:// www.smartpls.com.

Sarstedt, M., Hair Jr, J.F., Cheah, J.H., Becker, J.M. \& Ringle, C.M. 2019. How to specify, estimate, and validate higherorder constructs in PLS-SEM. Australasian Marketing Journal 27(3): 197-211.

Sarstedt, M., Ringle, C.M. \& Hair, J.F. 2017. Partial least squares structural equation modeling, In Handbook of Market Research, edited by Homburg, C., Klarmann, M. \& Vomberg, A. (Eds). Heidelberg: Springer,

Savaneviciene, A., Statnicke, G. \& Vaitkevicius, S. 2019. Individual innovativeness of different generations in the context of the forthcoming society 5.0 in Lithuania Inzinerine. Ekonomika-Engineering Economics 30(2): 211-222

Scherer, R., Siddiq, F. \& Tondeur, J. 2019. The technology acceptance model (TAM): A meta-analytic structural equation modelling approach to explaining teachers' adoption of digital technology in education. Computers \& Education 128: 13-35.

Scott, S. G. \& Bruce, R.A. 1994. Determinants of innovative behavior: A path model of individual innovation in the workplace. Academy of Management Journal 37(3): 580607.

Shmueli, G., Sarstedt, M., Hair, J. F., Cheah, J. H., Ting, H., Vaithilingam, S. \& Ringle, C. M. 2019. Predictive model assessment in PLS-SEM: Guidelines for using PLSpredict. European Journal of Marketing 53(11): 2322-2347.

Sigala, M., Christou, E. \& Gretzel, U. 2012. Social Media in Travel, Tourism and Hospitality: Theory, Practice and Cases. Ashgate Publishing Ltd.

Slatten, T. \& Mehmetoglu, M. 2015. The effects of transformational leadership and perceived creativity on innovation behavior in the hospitality industry. Journal of Human Resources in Hospitality \& Tourism 14(2):195219.

Sony, M. \& Naik, S 2019. Key ingredients for evaluating Industry 4.0 readiness for organizations: A literature review. Benchmarking: An International Journal 27(7): 2213-2232.

Taherdoost, H. 2018. A review of technology acceptance and adoption models and theories. Procedia Manufacturing 22: $960-967$

Taylor, M., Haggerty, J., Gresty, D., Pacheco, N.C., Berry, T. \& Almond, P. 2015. Investigating employee harassment via social media. Journal of Systems and Information Technology 17(4): 322-335

Tenenhaus, M., Esposito Vinzi, V., Chatelin, Y.M. \& Lauro, C. 2005. PLS path modeling. Computational Statistics \& Data Analysis 48(1): 159-205.

Thurlings, M., Evers, A.T. \& Vermeulen, M. 2014. Toward a model of explaining teachers' innovative behaviour: A literature review. Review of Educational Research 85(3): 430-471.

Trapero, F.G.A., Astaño, L.E.V., Parra, J.C.V. \& Garcia, J.G. 2017. Differences on self-perception of organizational pride and loyalty in Millennial \& Generation X, considering gender and seniority variables. Business and Economic Horizons 13(2): 270-286.

Tsimonis, G. \& Dimitriadis, S. 2014. Brand strategies in social media. Marketing Intelligence \& Planning 32(3): 328344. 
Twenge, J.M. 2010. A review of the empirical evidence on generational differences in work attitudes. Journal of Business and Psychology 25: 201-210.

Twenge, J.M. \& Campbell, W.K. 2008. Increases in positive self-views among high school students: Birth cohort changes in anticipated performance, self-satisfaction, selfliking, and self-competence. Psychological Science 19: 1082-1086.

Vui-Yee, K. \& Paggy, K. 2018. The effect of work fulfilment on job characteristics and employee retention: Gen Y employees. Global Business Review 21(2): 1-15.

Wang, Y. \& Zhu, X. 2018. Literature review of employees' innovative behavior. International Journal of Science 5(10): 1813-4890.

Wang, Y., Chen, Y., \& Zhu, Y. 2021. Promoting innovative behavior in employees: The mechanism of leader psychological capital. Frontiers in Psychology 11: 3797.

Wrzesniewski A. \& Dutton J.E. 2001. Crafting a job: Revisioning employees as active crafters of their work Academic of Management Review 28(2):179-201.

West, M.A. \& Sacramento, C.A. 2012. Creativity and innovation: The role of team and organizational climate.
In Handbook of Organizational Creativity, edited by M. Mumford, 359-385. London, UK: Academic Press.

Wu, P.F. 2009. User acceptance of emergency alert technology: A case study. In Proceedings of the 6th International ISCRAM Conference 2009: Gothenburg, Sweden.

Zelga, K. 2018. Managing Generation Y employees in the enterprise. World Scientific News WSN 104: 440-450.

Zhao, X., Lynch Jr, J. G., \& Chen, Q. 2010. Reconsidering Baron and Kenny: Myths and truths about mediation analysis. Journal of Consumer Research 37(2): 197-206.

Roshayati Abdul Hamid (penulis koresponden)

Fakulti Ekonomi dan Pengurusan

Universiti Kebangsaan Malaysia

43600 UKM Bangi, Selangor, MALAYSIA.

E-Mel: wanrose@ukm.edu.my

Ida Rosnita Ismail

UKM-Graduate School of Business

Universiti Kebangsaan Malaysia,

43600 UKM Bangi, Selangor, MALAYSIA.

E-Mel: idarosnita@ukm.edu.my 


\section{LAMPIRAN A}

JADUAL A. Hasil dapatan bagi model pengukuran reflektif

\begin{tabular}{|c|c|c|c|c|c|c|}
\hline Konstruk & Indikator & $\begin{array}{l}\text { Nilai bebanan } \\
\text { indikator }\end{array}$ & $\begin{array}{l}\text { Kebolehpercayaan } \\
\text { indikator }\end{array}$ & $\begin{array}{l}\text { Cronbach's } \\
\text { alpha }\end{array}$ & $\begin{array}{l}\text { Kebolehpercayaan } \\
\text { komposit }\end{array}$ & $\begin{array}{l}\text { Kesahan } \\
\text { konvergen (AVE) }\end{array}$ \\
\hline \multirow[t]{7}{*}{ Kebolehgunaan } & US1 & 0.819 & 0.671 & \multirow[t]{7}{*}{0.885} & \multirow[t]{7}{*}{0.912} & \multirow[t]{7}{*}{0.6} \\
\hline & US2 & 0.767 & 0.588 & & & \\
\hline & US3 & 0.765 & 0.585 & & & \\
\hline & US4 & 0.840 & 0.706 & & & \\
\hline & US5 & 0.871 & 0.759 & & & \\
\hline & US6 & 0.758 & 0.575 & & & \\
\hline & US7 & 0.562 & 0.316 & & & \\
\hline \multirow{3}{*}{$\begin{array}{l}\text { Kemudahan } \\
\text { penggunaan }\end{array}$} & US8 & 0.894 & 0.799 & \multirow[t]{3}{*}{0.867} & \multirow[t]{3}{*}{0.918} & \multirow[t]{3}{*}{0.79} \\
\hline & US9 & 0.877 & 0.769 & & & \\
\hline & US10 & 0.894 & 0.799 & & & \\
\hline \multirow{2}{*}{$\begin{array}{l}\text { Penggunaan } \\
\text { media sosial di } \\
\text { tempat kerja }\end{array}$} & Kebolehgunaan & 0.934 & 0.872 & \multirow[t]{2}{*}{0.657} & \multirow[t]{2}{*}{0.844} & \multirow[t]{2}{*}{0.731} \\
\hline & $\begin{array}{l}\text { Kemudahan } \\
\text { penggunaan }\end{array}$ & 0.768 & 0.590 & & & \\
\hline \multirow{6}{*}{$\begin{array}{l}\text { Karakteristik kerja } \\
\text { Milenial }\end{array}$} & $\mathrm{C} 1$ & 0.812 & 0.659 & \multirow[t]{6}{*}{0.827} & \multirow[t]{6}{*}{0.874} & \multirow[t]{6}{*}{0.538} \\
\hline & $\mathrm{C} 2$ & 0.725 & 0.526 & & & \\
\hline & $\mathrm{C} 3$ & 0.725 & 0.526 & & & \\
\hline & $\mathrm{C} 4$ & 0.696 & 0.484 & & & \\
\hline & $\mathrm{C} 5$ & 0.816 & 0.666 & & & \\
\hline & $\mathrm{C} 6$ & 0.608 & 0.370 & & & \\
\hline \multirow{9}{*}{$\begin{array}{l}\text { Tingkahlaku } \\
\text { inovatif pekerja } \\
\text { Milenial }\end{array}$} & IN1 & 0.607 & 0.368 & \multirow[t]{9}{*}{0.901} & \multirow[t]{9}{*}{0.919} & \multirow[t]{9}{*}{0.561} \\
\hline & IN2 & 0.686 & 0.471 & & & \\
\hline & IN3 & 0.724 & 0.524 & & & \\
\hline & IN4 & 0.788 & 0.621 & & & \\
\hline & IN5 & 0.769 & 0.591 & & & \\
\hline & IN6 & 0.767 & 0.588 & & & \\
\hline & IN7 & 0.845 & 0.714 & & & \\
\hline & IN8 & 0.740 & 0.548 & & & \\
\hline & IN9 & 0.788 & 0.621 & & & \\
\hline
\end{tabular}

